\title{
SIZE IN RELATION TO SALINITY IN FOSSIL AND RECENT EURYHALINE OSTRACODS
}

\author{
By DENNIS BARKER \\ Department of Geology, University of Leicester
}

(Text-figs. I-4)

\section{FOSSIL OSTRACODS}

During a recent study of the ostracod faunas of the Portland and Purbeck Beds of the Aylesbury district (a full account of which is in preparation) a euryhaline ostracod fauna was reported. The ostracods in question are Fabanella polita Martin and Fabanella ansata (Jones). A study was made of their vertical distribution at three localities: (a) at the Bugle Pit, Hartwell, (b) at a temporary roadside section I mile north of Whitchurch on the west side of the Buckingham road, and at (c) Warren House Farm, Stewkley.

It was found possible to subdivide the beds at these localities into a number of facies characterized in the main by ostracod faunas. At the base are (i) the massive cream coloured limestones of the Portlandian with marine ostracods and referred to as the Portland facies. Above these are (ii) laminated marls and limestones with a mixture of marine and euryhaline ostracods referred to as the marine Purbeck facies, (iii) laminated marls and limestones with euryhaline ostracods referred to as the brackish Purbeck facies, and (iv), marls and limestones becoming sandy upwards with freshwater-oligohaline ostracods referred to as the freshwater Purbeck facies. These facies demonstrate a gradual change from marine Portland conditions to the more or less freshwater beds of the Purbeck.

Fabanella was found in facies (i), (ii), and (iii), and it was noticed that there seemed to be a slight difference in size between specimens in each of the three facies.

All the specimens of Fabanella were measured from the bed in each facies with the largest number of specimens; the results for each locality are shown in Figs. I and 2. Histograms are drawn for the lengths of the ostracods from the various beds at each locality. Inspection shows that the range of length of the instars overlap. To calculate the separate statistics for the instars represented, the results were plotted on arithmetic probability paper. A normal distribution plotted on this paper produces a straight line, and if a bimodal or polymodal distribution is made up from a series of normal distributions then a curve will be produced which is the resultant of two or more straight lines. Using a method described by Harding (I949) the position of these 
BUGLE PIT, HARTWELL.

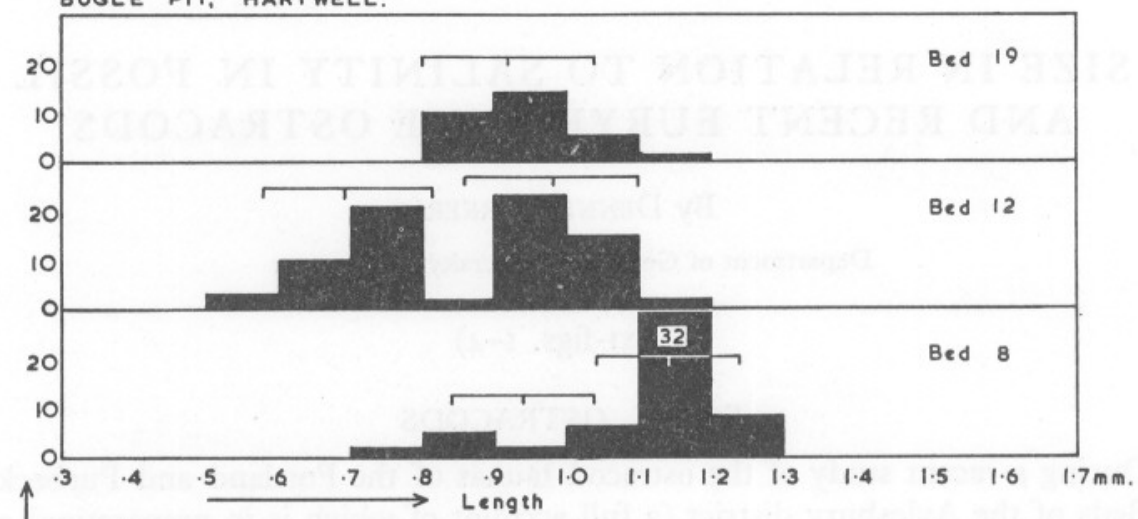

NORTH WHITCHURCH.

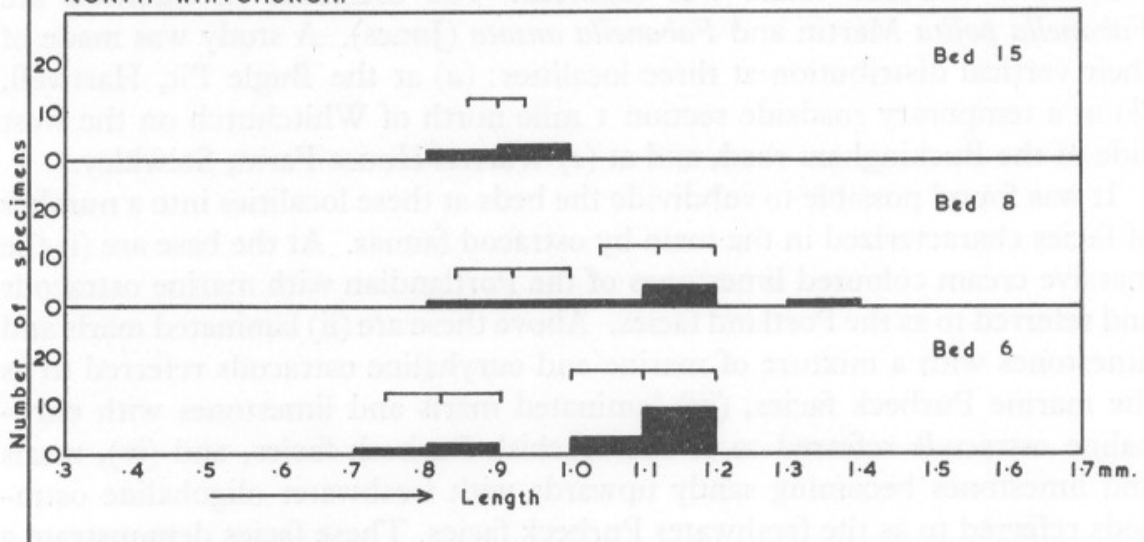

WARREN HOUSE FARM.

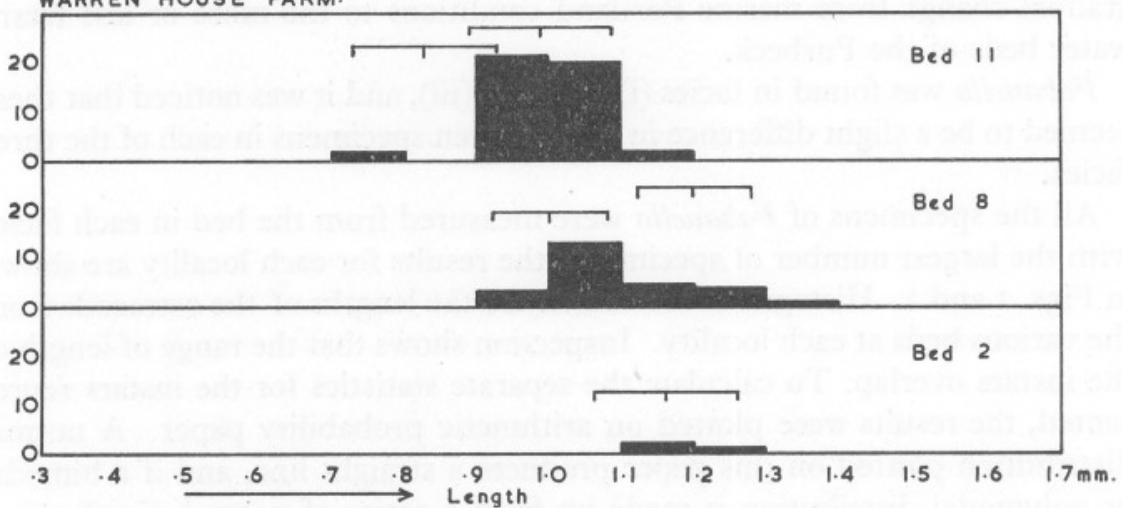

Fig. I. The relative lengths of specimens of Fabanella ansata from beds in the three sections. The range $(\bar{X} \pm 2 s)$ is indicated for each bed. 

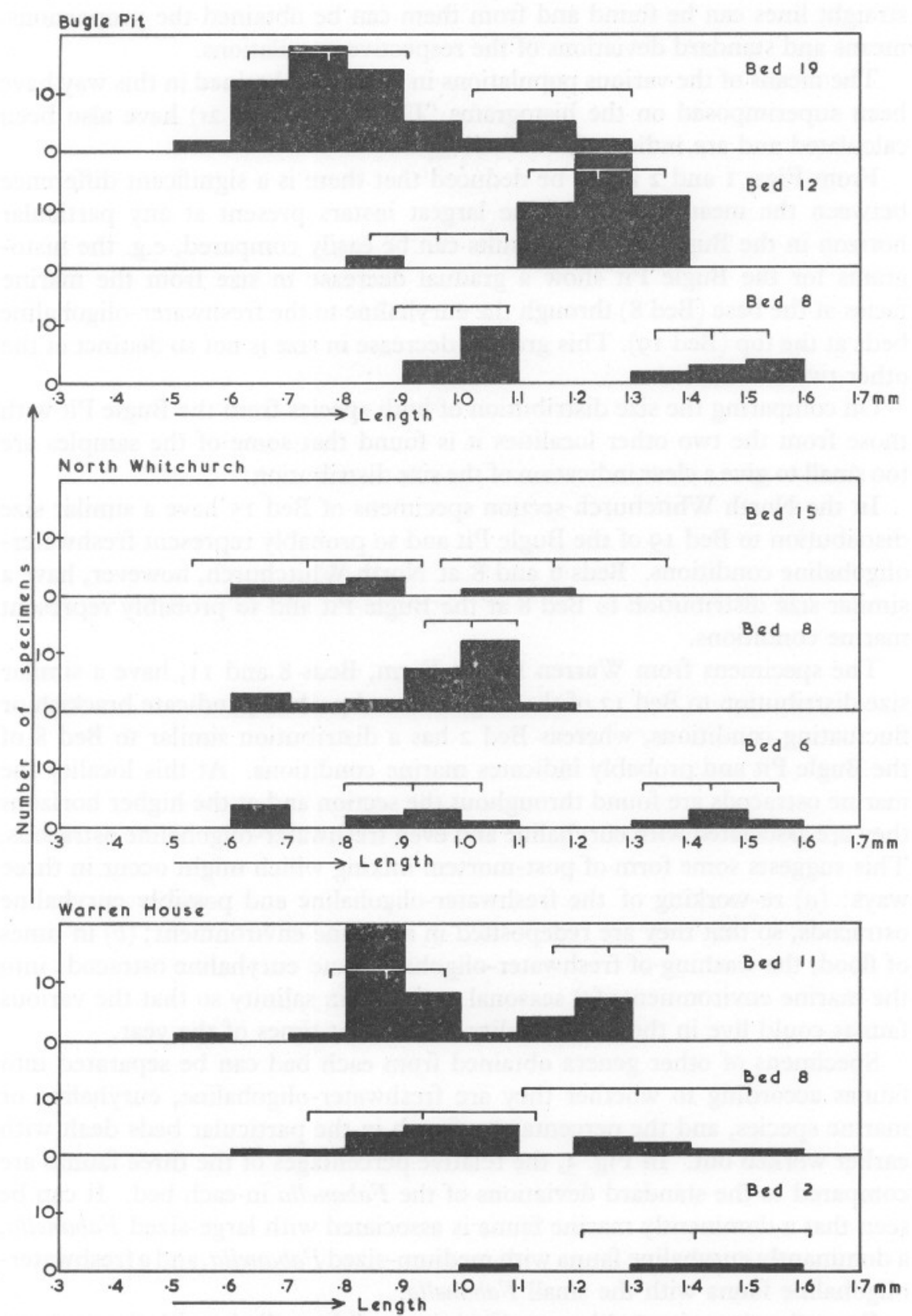

Fig. 2. The relative lengths of specimens of Fabanella polita from beds in the three sections. The range $(\bar{X} \pm 2 s)$ is indicated for each bed. 
straight lines can be found and from them can be obtained the proportions, means and standard deviations of the respective populations.

The means of the various populations in each bed obtained in this way have been superimposed on the histograms. The ranges $(\bar{X} \pm 2 s)$ have also been calculated and are indicated.

From Figs. I and 2 it can be deduced that there is a significant difference between the mean lengths of the largest instars present at any particular horizon in the Bugle Pit. The results can be easily compared, e.g. the histograms for the Bugle Pit show a gradual decrease in size from the marine facies at the base (Bed 8) through the euryhaline to the freshwater-oligohaline beds at the top (Bed I9). This gradual decrease in size is not so distinct at the other two localities.

On comparing the size distribution of both species from the Bugle Pit with those from the two other localities it is found that some of the samples are too small to give a clear indication of the size distribution.

In the North Whitchurch section specimens of Bed I5 have a similar size distribution to Bed I9 of the Bugle Pit and so probably represent freshwateroligohaline conditions. Beds 6 and 8 at North Whitchurch, however, have a similar size distribution to Bed 8 at the Bugle Pit and so probably represent marine conditions.

The specimens from Warren House Farm, Beds 8 and II, have a similar size distribution to Bed I2 of the Bugle Pit and probably indicate brackish or fluctuating conditions, whereas Bed 2 has a distribution similar to Bed 8 of the Bugle Pit and probably indicates marine conditions. At this locality the marine ostracods are found throughout the section and at the higher horizons they are associated with euryhaline and even freshwater-oligohaline ostracods. This suggests some form of post-mortem mixing which might occur in three ways: (a) re-working of the freshwater-oligohaline and possibly euryhaline ostracods, so that they are redeposited in a marine environment; $(b)$ in times of flood, the washing of freshwater-oligohaline and euryhaline ostracods into the marine environment; $(c)$ seasonal variation in salinity so that the various faunas could live in the same locality at different times of the year.

Specimens of other genera obtained from each bed can be separated into faunas according to whether they are freshwater-oligohaline, euryhaline or marine species, and the percentages of each in the particular beds dealt with earlier worked out. In Fig. 3, the relative percentages of the three faunas are compared to the standard deviations of the Fabanella in each bed. It can be seen that a dominantly marine fauna is associated with large-sized Fabanella, a dominantly euryhaline fauna with medium-sized Fabanella, and a freshwateroligohaline fauna with the small Fabanella.

From the above it would seem that it is possible to distinguish the environment of a particular bed according to the size distribution of the euryhaline ostracods present in the bed. 
Fabanella ansato

BUGLE PIT, HARTWELL.

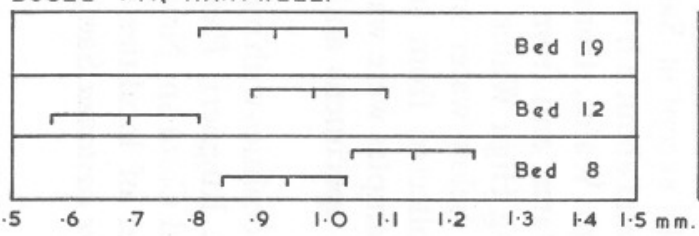

NORTH WHITCHURCH.

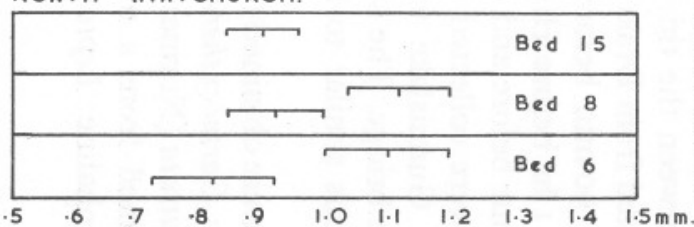
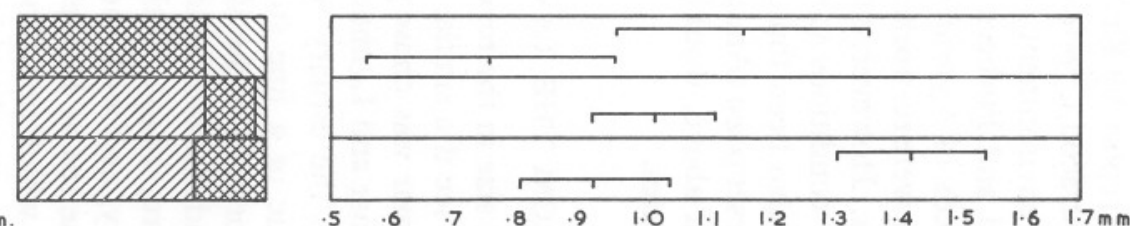

WARREN HOUSE FARM.
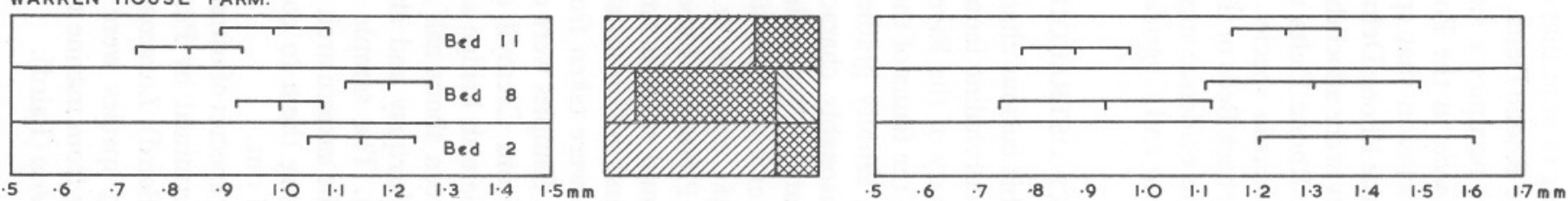

FRESHWATER-OLIGOHALINE FAUNA.

Fabanella polita

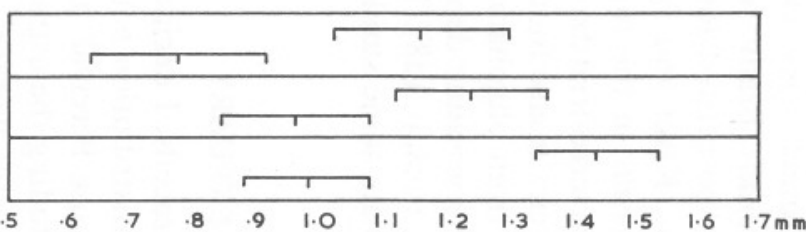

Fig. 3. The relationship between the size distributions of Figs. I and 2, and, in the central column, the proportions of the ostracod faunas in each bed. 
It is interesting to note that in the report by Kruit \& Andel (1955) on the Sediments of the Rhone Delta, the ostracod Cyprideis littoralis (Brady) forma littoralis (Brady) occupies a similar environment to that postulated for the species of Fabanella in the Portland and Purbeck Beds. Kruit and Andel came to the conclusion that specimens of Cyprideis littoralis in the marine environment of the Rhone Delta slope were re-worked from terrestrial deposits close by, i.e. they were allochthonous. However, this species is also found in the lakes of the Rhone Delta under conditions varying from oligohaline to supersaline. Fabanella species have also been found in supersaline deposits of the Lower Purbeck Beds of the Dorset coast (Anderson, I958, p. I28). This, together with the evidence suggested above, would indicate some similarity between Fabanella and Cyprideis species.

\section{RECENT OSTRACODS FROM THE TAMAR ESTUARY}

On account of this curious change in size in the fossil ostracods, I decided to examine recent euryhaline faunas to see if a similar size distribution is to be found. The estuary of the River Tamar was chosen because Percival (I929) had reported on the fauna of the Tamar and Lynher, excluding the ostracods but including a salinity gradient up the estuary which later workers have found to be reasonably characteristic of a fine summer. During 1936-40 several workers at the Plymouth Laboratory of the Marine Biological Association carried out extensive physical and faunistic studies of the Tamar estuary (see Milne, 1938; Spooner \& Moore, 1940). With the permission of the Director of the Plymouth Laboratory, and with the help of the staff, I was able to collect mud samples from the sea at Drake's Island and from other places as far inland as Gunnislake, at which point the river has become freshwater. Samples were taken from between the tide marks except at Saltash and Gunnislake. Samples were collected from Drake's Island about $2 \mathrm{~h}$ before High Water. From Cremyll about $90 \mathrm{~min}$ before High Water, from the channel below Saltash bridge about I hr before High Water, and from Neil Point and Cargreen about half an hour before and during High Water. The samples from Weirquay and above were collected from below water in the inter tidal areas. The sample from Gunnislake was collected from sandy gravel beneath the eastern arch of the bridge. The mud samples were washed and dried to bring them to conditions similar to fossil specimens and the ostracods picked out.

The following species of ostracods were obtained from localities with marine salinities as determined by Percival: Carinocythereis sp. Ruggieri, Pterygocythereis jonesi (Baird), Loxoconcha guttata (Norman), and Costa sp. Neviani.

The following species were obtained from a number of localities with salinities varying from marine to oligohaline: Leptocythere castanea Sars, and Loxoconcha impressa (Baird). 
Aurila convexa (Baird) was found in marine to mesohaline conditions only. Candona candida (O. F. Müller) was the only ostracod obtained from a freshwater environment.

Fig. 4 indicates the localities on the River Tamar from which collections were made. Also on this diagram is a simplified version of the salinity gradient obtained by Percival. The size distributions of Leptocythere castanea Sars and Loxoconcha impressa (Baird) obtained from various localities are shown as histograms. The histograms show a sharp decrease in size between Cargreen and Weirquay, which correlates with a sharp decrease in salinity on the salinity gradient.

It should also be noted that the collections of recent ostracods were made during August and September I96I and that collections made at other times of the year may not be quite the same, owing to variations in the breeding and feeding habits of the ostracods throughout the year, and to the reduction of salinity during winter spates.

\section{FACTORS CONTROLLING SIZE}

The evidence of both fossil and recent ostracod faunas indicated above shows a significant correlation between salinity and size. Salinity, however, is not necessarily the controlling factor since other environment conditions may be correlated with salinity and these may be responsible for the variations in size, for example temperature, current action, and $\mathrm{pH}$.

\section{Salinity}

Faunas which are adapted to narrow ranges of salinity would be unable to adapt themselves to other salinities. Features such as stunting might develop and eventually the animals would die off. However, the euryhaline faunas capable of existing in a wide range of salinities might be able to make use of the increased salts in the more saline waters for the construction of larger carapaces.

In the Portland and Purbeck sediments determination of the salinity can be made between broad limits indicated by the association of fossils, minerals and sedimentation.

In the River Tamar the effect of the tide is very strong, carrying large quantities of fine grade material in suspension, some of which is left behind as it retreats. Amongst the suspension could be ostracod larvae some of which could be stranded by the tide but continue to exist in the interstitial water which in an estuary at low tide is more saline than the water above it (Reid, I930, I932; Alexander, Southgate \& Bassindale, I932). When the larvae become strong enough they would be able to migrate downstream to more saline conditions with the help of later tides. In this way marine forms might adjust themselves to freshwater conditions, but it would be more difficult for fresh- 

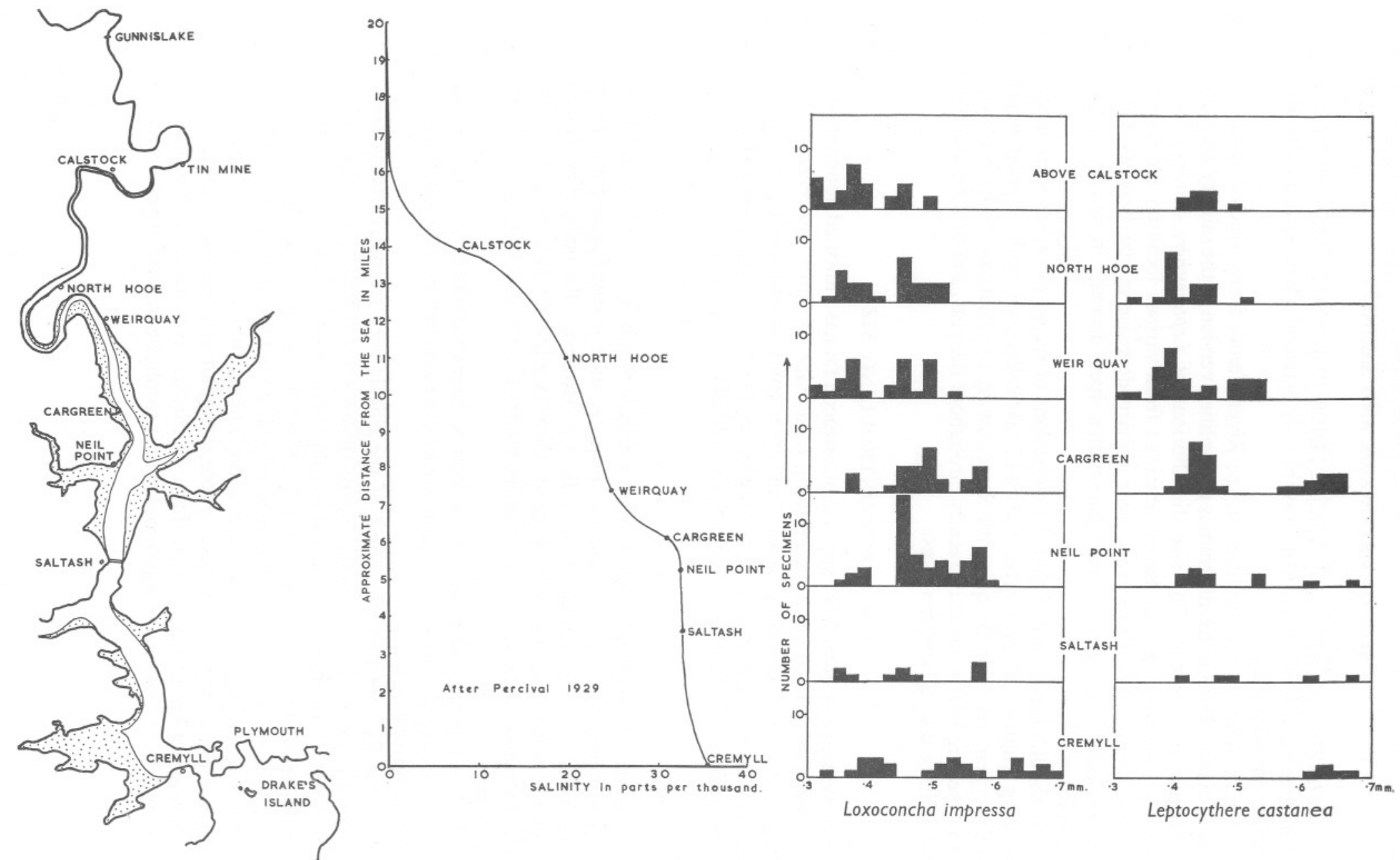

Fig. 4. A composite diagram to show the collection points on the River Tamar compared to a graph of the variation of salinity with distance from the sea and also to the size distributions of Loxoconcha impressa and Leptocythere castanea at the various localities. 
water forms to adjust themselves to salt water. Also, only the smaller juvenile forms would be found upstream. It is difficult to determine from the histograms in Fig. 4 whether the decrease in size is in the adult form or due to juvenile moult stages. This could only be determined by further sampling but just from inspection it would appear that the change in size was in the adult form.

\section{Temperature}

The most important competitor to salinity is probably the effect of differences in temperature. This is borne out by the evidence of Elofson (I94I) who verified Skogsberg's 1920 findings that Philomedes globosus was larger in the colder waters near Greenland than in the North Sea and the Skagerak. $\mathrm{He}$ also found that Cytherura nigrescens (Baird) from one locality were larger in each instar in winter than in summer.

Fischer-Piette (I93I, I933) compared the distribution of various species (not ostracods) mainly occurring on rock substrata in the Rance estuary, France. Observations during unusually wet and unusually dry years showed that salinity and not temperature is the factor controlling the limit of penetration of many estuarine species.

Milne (1938) showed that there was an increase in the range of temperature from Drake's Island to Saltash. Sharp changes of temperature would cause reduced activity and if this occurred during moulting some reduction in growth could be expected. In the summer large changes in temperature would occur, e.g. when the tides washed over the hot mud flats. Extremes of temperature would occur on the whole infrequently and only for a short period, longer periods of course would be lethal. Salinity decreases upstream and for an ostracod in a particular place and season is fairly constant since they live mostly in the interstitial water. The most constant control is salinity, any changes in which would affect the ostracods for long periods.

\section{Current action}

In fossil forms there is the possibility of current action which would sort the valves into sizes. However, the modes of the histograms, especially that of the Bugle Pit, occur in intermediate positions, i.e. in Fig. 2, the mode for the largest forms in Bed I 2 of the Bugle Pit section is between the largest two modes of Bed 8, and is just in front of the largest mode in Bed I9. No method of current sorting could create modes between instars.

In a normal river there is a decrease in size of sediment downstream. However, in tidal estuaries sedimentation is also from the sea, the finest sediment being carried farthest upstream in the tidal region. There is also some grading of the sediment across a river or estuary with the finest sediment being near the bank and the coarsest in the main river channel. Thus two systems of 
sedimentation are at work and the sediment is passed up and down the river, being reworked all the time. The samples were in all cases from the muddy silty material. Therefore, since the ostracods are much larger in size than the silt they are found in, the effect of sediment sorting would be of consequence in juvenile and larval stages as mentioned earlier.

\section{Preparation of samples}

As all samples were prepared in the same manner any effect of preferential breakage of the larger specimens should give the same results in each sample.

\section{Other factors}

Little is known about the effects of redox potential and hydrogen ion concentration on size. Milne (1938) showed that in the Tamar estuary there was apparently no correlation between $\mathrm{pH}$ and salinity.

\section{Conclusion}

From the above discussion it is suggested that the variation in the size of euryhaline ostracods is likely to be caused by changes in the salinity of the water. This decrease in size with decrease in salinity is corroborative evidence for the idea that in the Aylesbury district there was a transition from marine Portland conditions to freshwater Purbeck conditions towards the end of the Jurassic period.

The author would like to extend his thanks to Prof. P. C. Sylvester-Bradley for his helpful criticism and guidance of this research; to the Director and staff of the Marine Biological Laboratory at Plymouth, for help in collecting the specimens of recent ostracods; to Dr F. W. Anderson for reading the script and also to Prof. H. P. Moon and Mr H. F. Downton for helpful discussions. This work was carried out partly during the tenure of a University of Leicester Research Scholarship.

\section{SUMMARY}

Variation in size of fossil euryhaline ostracods is discussed and compared to size variation in recent forms. The most likely cause of variation in size of euryhaline ostracods is variation in salinity. Similarities are indicated between Fabanella and Cyprideis species. 


\section{REFERENCES}

Alexander, W. B., Southgate, B. A. \& Bassindale, R., I932. The salinity of the water retained in the muddy foreshore of an estuary. F. mar. biol. Ass. U.K., Vol. I8, pp. 297-298.

Anderson, F. W., I958. Geology of the country around Bridport and Yeovil. Mem. geol. Surv. U.K.

Elofson, O., I94I. Zur Kenntnis der marinen Ostracoden Schwedens mit besonderer Berücksichtigung des Skageraks. Zool. Bidr. Uppsala, Bd. 19, pp. 215-534, 52 figs., 42 maps.

Fischer-Piette, E., I93I. Sur la pénétration des diverses espèces marines sessiles dans les estuaries et sa limitation par l'eau douce. Ann. Inst. océanogr. Monaco, T. IO, pp. 213-43.

— I933. Nouvelles observations sur l'ordre d'euryhalinité des espèces litorales. Bull. Inst. océanogr. Monaco, No. 619, pp. I-I6.

HARDING, J. P., I949. The use of probability paper for the graphical analysis of polymodal frequency distributions. F. mar. biol. Ass. U.K., Vol. 28, pp I4I-53.

KRUIt, C. \& ANDEL van TJ. H., 1955. Sediments of the Rhone Delta. Verh. Nederl. geol.-mijn. Genootsch., Geol., Vol. 15, pp. 357-556, pls. I-6.

Milne, A., I938. The Ecology of the Tamar Estuary. III. Salinity and temperature conditions in the lower estuary. F. mar. biol. Ass. U.K., Vol. 22, pp. 529-42, figs. I-5.

Percival, E., 1929. A report on the fauna of the estuaries of the Tamar and Lynher. F. mar. biol. Ass. U.K., Vol. 16, pp. 81-108.

ReID, D. M., I930. Salinity interchange between salt-water in sand and the overflowing fresh-water, at low tide. I. F. mar. biol. Ass. U.K., Vol. I6, pp. 609-I4. 1932. Salinity interchange between salt-water in sand and overflowing freshwater at low tide. II. f. mar. biol. Ass. U.K., Vol. I8, pp. 299-306.

Skogsberg, T., I920. Studies on marine ostracods. Part I. Cypridinids, halocyprids, polycopids. Zool. Bidr. Uppsala, Suppl. Bd. I, 784 pp., I53 figs.

SPooner, G. M. \& Moore, H. B., I940. The ecology of the Tamar Estuary. VI. An account of the macrofauna of the intertidal muds. F. mar. biol. Ass. U.K. Vol. 24, pp. 283-330. 